International Journal of Research in Engineering and Innovation
(IJREI)
IJREI

\title{
Different analytical methods for the determination of metronidazole $-\mathrm{A}$ review
}

\author{
Sarra A. Abrahem ${ }^{1}$, Abdul kader S ${ }^{2}$, Suhad A. Ibrahim ${ }^{1}$ \\ ${ }^{I}$ Department. of Chemistry, College of Science at Al-Nahrain University, Baghdad, Iraq \\ ${ }^{2}$ Minister's office, Ministry of higher education and scientific research, Baghdad, Iraq.
}

\begin{abstract}
Keywords: Metronidazole, ISE, HPLC, Spectrophotometric

\section{Introduction}

Metronidazole is a 5-nitronimidazole derivative and is widely used for treating bacterial infections due to it's effectively towards anaerobic bacteria and anaerobic protozoa [2]. Topical metronidazole (Metrogel) is used to treat a skin condition known as rosacea. Its gel form is often used to treat vaginal bacterial infections [1]. It has the formula $\mathrm{C} 6 \mathrm{H} 9 \mathrm{~N} 3 \mathrm{O} 3$, shown in figure [1], and a molecular weight of $171.156 \mathrm{~g} \cdot \mathrm{mol}-1$. Its chemical structure is [2- (2- methyl - 5 -nitroimidazole-1-yl) ethanol]. Metronidazole has a slight odor and is available in the form of crystalline powder of a light yellow to white color [1]. Several analytical methods were conducted by scholars to determine metronidazole. These methods included: Concentration range, limit of detection, recovery, life time, and type of column, mobile phase, slope, retention time, reduction peak current and the range of $\mathrm{PH}$ for metronidazole. The results of reviewing these methods in this study were listed in tables $1,2,3$. In addition, there were other analytical methods for the determination of metronidazole, such as: Photo-Fenton Oxidation Technology [3], and ChargeTransfer Complexes Formation [4].
\end{abstract}

Metronidazole is available in most areas of the world and is often used for treating bacterial infections in various parts of human body including the liver, brain, joints, vagina, skin, heart, respiratory tract, and stomach or intestines. Therefore, it is essential to develop simple and low-cost analytical methods for such a compound in order to advance quality control. In this paper, various analytical papers that identify metronidazole in commercial preparations and biological samples have been analyzed and reviewed. The reviewed literature included spectrophotometric, chromatography, and ion selective electrodes.

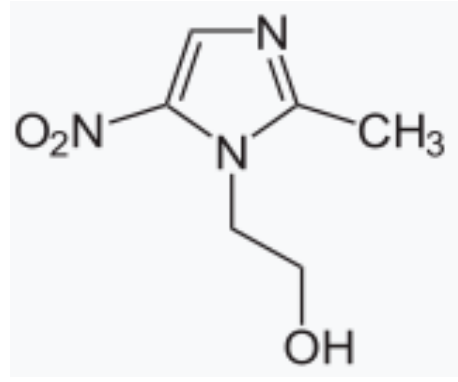

(a)

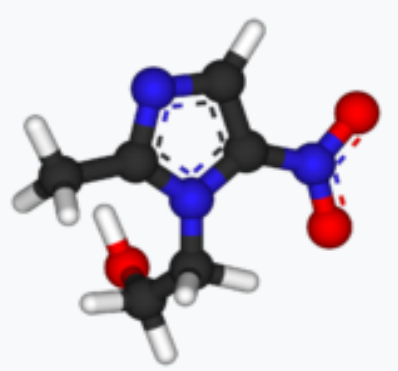

(b)

Figure 1: (a) 2D chemical structures of Metronidazole, (b) 3D chemical structures of Metronidazole. 
Table 1: Ion Selective Electrodes for Determination of Metronidazole.

\begin{tabular}{|c|c|c|}
\hline Type of Ion pair for Electrodes & Results & Ref. \\
\hline $\begin{array}{l}\text { Electrochemical ultrasensitive sensor using } \\
\text { carbonnano, multi-walled } \\
\text { polydopamine/carboxylic - tubes } \\
\text { (MWCNTs_COOH) nano composites using } \\
\text { improved (GCE) glassy carbon electrode. }\end{array}$ & $\begin{array}{l}\text { Conc. Range: } 5 \text { to } 5000 \mu \mathrm{mol} / \mathrm{dm}^{3} \text {. } \\
\text { Detection limit: }(\mathrm{S} / \mathrm{N}=3) 0.25 \mu \mathrm{mol} / \mathrm{dm}^{3} \text {. } \\
\text { pH: } 5.0 \text { to } 11.0 \text {. } \\
\text { Reduction peak current: remained } 95.2 \% \text { of its initial } \\
\text { value. } \\
\text { Recovery: Between } 93.4 \% \text { and } 118.3 \% \text {. } \\
\text { Life time: } 1 \text { month. }\end{array}$ & {$[5]$} \\
\hline $\begin{array}{l}\text { (MNZ) metronidazole based on 1-butyl-3- } \\
\text { methylimidazolium tetrafluoroborate as (IL) ionic } \\
\text { liquid and (SWCNT) single walled carbon } \\
\text { nanotube. Using IL in the paste, as a binder, } \\
\text { increased the electrode response. }\end{array}$ & $\begin{array}{l}\text { Conc. Range: Between } 5.00 \times 10^{-5} \text { and } 5.00 \times 10^{-3}\left(\mathrm{mgL}^{-1}\right) \text {. } \\
\text { Detection limit: } 1.238 \times 10^{-5}\left(\mathrm{mgL}^{-1}\right) \text {. } \\
\text { pH: } 2.0 \text { to } 10.0 \text {. } \\
\text { Reduction peak current: }-0.7 \pm 0.05 \mathrm{~V} \text {. } \\
\text { Recovery: } 90.33-108.0 \% \text {. }\end{array}$ & {$[6]$} \\
\hline $\begin{array}{l}\text { Quantitative and simultaneous (MT) } \\
\text { metronidazole detection utilizing (PCHAGCE); } \\
\text { (chromotrope 2B) poly, modified, activated glassy } \\
\text { carbon electrode }\end{array}$ & $\begin{array}{l}\text { Conc. Range: } 1.0 \times 10^{-5}-4 \times 10^{-4} \mathrm{~mol} / \mathrm{L} \text {. } \\
\text { Detection limit: }(\mathrm{S} / \mathrm{N}=3) 3.3 \times 10^{-7} \mathrm{~mol} / \mathrm{L} \text {. } \\
\text { pH: } 4.0-9.0 \text {. } \\
\text { Reduction peak current: }-0.58 \mathrm{~V} \text {. } \\
\text { Recovery: } 99.0-103.0 \% \text {. } \\
\text { Life time: } 2 \text { weeks. }\end{array}$ & [7] \\
\hline $\begin{array}{l}\text { A sensor of amperometric metronidazole (MTZ) } \\
\text { utilizing a recognition element (glycosylated } \\
\text { metalloporphyrin) combined with a carbon paste } \\
\text { electrode. For the preparation of a MTZ - sensitive } \\
\text { active material, } 5,10,15,20 \text { - tetrakis }[2-(2,3,4 \text {, } \\
6 \text { - tetraacetyl - } \beta \text { - D -glucopyranosyl) - } 1 \text { - O - } \\
\text { phenyl] porphyrin (T (oglu) PPH2) and its Mn } \\
\text { (III) complex, MnT (o-glu) PPCl . }\end{array}$ & $\begin{array}{l}\text { Conc. Range: From } 2.9 \times 10^{-3} \text { to } 5.8 \times 10^{-8}(\mathrm{M} / \mathrm{L}) \text {. } \\
\text { Detection limit: } 5.8 \times 10^{-8}(\mathrm{M} / \mathrm{L}) \text {. } \\
\text { pH: } 4.3 \text {. } \\
\text { Reduction peak current: }-408 \mathrm{mV} \text {. } \\
\text { Life time: } 2 \text { months. }\end{array}$ & {$[8]$} \\
\hline
\end{tabular}

Table 2: HPLC for determination of Metronidazole.

\begin{tabular}{|c|c|c|}
\hline Methods & Results & Ref. \\
\hline HPLC & $\begin{array}{l}\text { Column: Eclipse XDB-phenyl column. } \\
\text { Mobil Phase: }(75: 25: 1, \mathrm{v} / \mathrm{v} / \mathrm{v}) \text { Sodium acetate }(0.05 \mathrm{M}) \text { : acetonitrile: glacial acetic acid, } \\
\text { using phosphoric acid to adjust the } \mathrm{pH} \text { ed to } 4.0 . \\
\text { Detector: UV detector, } \lambda: 320 \mathrm{~nm} \text {. } \\
\text { Conc. range: } 0.05-30 \mu \mathrm{g} / \mathrm{ml} \text {. } \\
\text { LOQ: } 0.05 \mu \mathrm{g} / \mathrm{ml} \text {. } \\
\mathrm{t}_{\mathrm{R}}: 4.06 \mathrm{~min} \text {. }\end{array}$ & [9] \\
\hline RP-HPLC & $\begin{array}{l}\text { Column: Column }(\mathrm{C} 18,0.5 \mu \mathrm{m}) \text {, Shimadzu LC-10ATvp (HPLC), particle size } \\
(150 \times 4.6 \mathrm{~mm}) \text {. } \\
\text { Mobil Phase: de-ionized water and HPLC grade methanol were mixed (ratio of } 650: 400 \\
\text { ml), using phosphoric acid to adjust the } \mathrm{pH} \text { to } 2.5 \text {. } \\
\text { Using vacuum filtration unit, a } 0.45 \mu \text { membrane was utilized to filter the mobile phase. } \\
\text { Then, ultrasonic bath was used for degassing for } 15 \mathrm{~min} \text {. } \\
\text { Detector: UV detector, } \lambda: 254 \mathrm{~nm} \text {. } \\
\text { Conc range: } 10-1000 \mu \mathrm{g} / \mathrm{ml} \text {. } \\
\text { LOD: } 0.0158 \mu \mathrm{g} \mathrm{ml} l^{-1} \text {. } \\
\text { tR: } 7.751 \pm 0.00025 \mathrm{~min}^{\text {m. }}\end{array}$ & {$[10]$} \\
\hline RP-HPLC & $\begin{array}{l}\text { Column: }(250 \times 4.6 \mathrm{~mm}) \text { column, LiChrosorb }{ }^{\circledR} \mathrm{RP}-18 \text {, packed with }(5-\mu \mathrm{m}) \text { octadecylsilyl } \\
\text { silica gel. } \\
\text { Mobil Phase: A solution of }(0.02: 20: 80 \mathrm{v} / \mathrm{v} / \mathrm{v}) \text { triethylamine, acetonitrile, and } 0.3 \% \mathrm{o}- \\
\text { phosphoric acid. } \\
\text { Detector: ShimadzuSPD- } 20 \mathrm{~A} \text { ultraviolet-visible (UV/VIS) detector, } \lambda: 290 \mathrm{~nm} \text {. } \\
\text { Conc range: } 12.5 \text { to } 100.0 \mu \mathrm{g} / \mathrm{ml} \text {. } \\
\text { LOD: } 0.125 \mu \mathrm{g} / \mathrm{ml} \text {. } \\
\mathbf{t}_{\mathbf{R}}: 3.42 \mathrm{~min} \text {. }\end{array}$ & {$[11]$} \\
\hline RP-HPLC-DAD & $\begin{array}{l}\text { Column: L- } 2300 \text { column oven, prepared with a } 250 \times 4.6 \mathrm{~mm} 2 \text { (i.d.), ODS column }(5 \mu \mathrm{m}) \text {. } \\
\text { Mobil Phase: Phosphate buffer }(50 \mathrm{mM}) \text { adjusted with } 1 \mathrm{M} \mathrm{HCl} \text { to a }(4.27 \pm 0.01) \mathrm{pH} \text { as } \\
\text { mobile phase A-methanol. } \\
\text { Detector: UV detector, } \lambda: 242 \mathrm{~nm} \text {. } \\
\text { Conc range: } 1-20 \mu \mathrm{g} / \mathrm{ml} \text {. } \\
\text { LOD: } 0.02 \mu \mathrm{g} / \mathrm{ml} \text {. } \\
\text { th }_{\mathrm{R}}: 5.5 \mathrm{~min} \text {. }\end{array}$ & [12] \\
\hline
\end{tabular}




\begin{tabular}{|c|c|c|}
\hline RP-HPLC & $\begin{array}{l}\text { Column: } 250 \text { x } 4.6 \mathrm{~mm}, 5 \mu \text { (Phenyl column). } \\
\text { Mobil Phase: Instead of (ACN) Acetonitrile, Propylene Carbonate:Methanol 60:40 } \\
\text { (Solvent-X) was used. } \\
\text { Detector: UV-Vis detector. } \\
\lambda: 310 \mathrm{~nm} . \\
\text { Conc range: } 1.0-2.4 \mu \mathrm{g} / \mathrm{mL} \text {. } \\
\text { LOD: } 15 \mathrm{ng} / \mathrm{ml} \text {. } \\
\mathbf{t}_{\mathbf{R}}: 5.2 \mathrm{~min} \text {. }\end{array}$ & [13] \\
\hline RP-HPLC & $\begin{array}{l}\text { Column: }(4.6 \times 150 \mathrm{~mm}) \text {, particle size }(5 \mu)(\mathrm{C}-18 \text { column }) \text {, Water's X-bridge. } \\
\text { Mobil Phase: a mixture of acetonitrile and phosphate buffer }(\mathrm{pH} 2.5) \text { in }(70: 30, \% \mathrm{v} / \mathrm{v}) \\
\text { ratio. } \\
\text { Detector: UV detector. } \\
\lambda: 220 \mathrm{~nm} . \\
\text { Conc range: } 10-30 \mu \mathrm{g} / \mathrm{mL} \text {. } \\
\text { LOD: } 0.042 \mu \mathrm{g} / \mathrm{mL} \text {. } \\
. t_{\mathbf{R}}: 3.157 \mathrm{~min} \text {. }\end{array}$ & [14] \\
\hline RP-HPLC & $\begin{array}{l}\text { Column: The performance of isocratic elution on a }(100 \mathrm{~mm} \times 4.6 \mathrm{~mm}) \text { Whatman }{ }^{\circledR} \text { Partisil } \\
5 \text { ODS- } 3 \text { column, }(\mathrm{RP}) \text { plus Whatman }{ }^{\circledR} \text { guard cartridge, particle size }\left(5 \_\mathrm{m}\right) \text {. } \\
\text { Mobil Phase: Degassing and filtering of }\left(0.45 \_\mathrm{m} \text {; Millipore }\right) \text { solution mixture of } \\
\text { phosphate buffer. A pH of }(4.7 ; 0.05 \mathrm{M})-\text { methanol }(95: 5, \mathrm{v} / \mathrm{v}) \text {. The } \mathrm{pH} \text { was adjusted to } \\
(4.0) \text {. } \\
\text { Detector: UV detector. } \\
\lambda: 254 \mathrm{~nm} \text {. } \\
\text { Conc range: } 0.13 \text { and } 300 \mu \mathrm{g} / \mathrm{mL} \text {. } \\
\text { LOD: } 0.1 \mu \mathrm{g} / \mathrm{mL} \\
\text { tR: } 6.8 \text { min. }\end{array}$ & [15] \\
\hline HPLC & 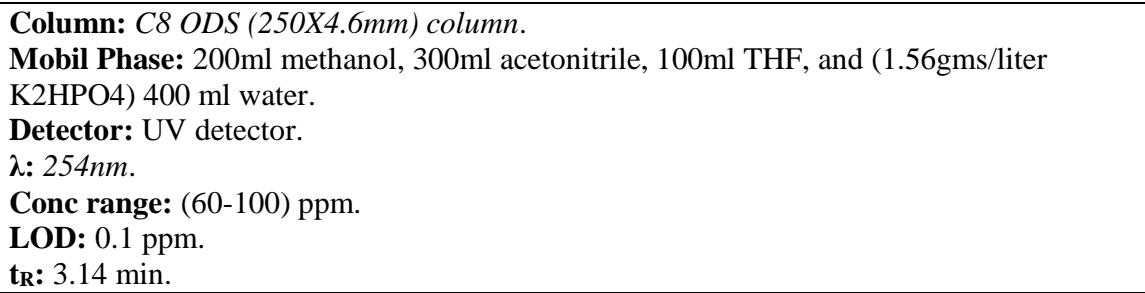 & [16] \\
\hline
\end{tabular}

Table 3: Spectrophotometric methods for determination of Metronidazole

\begin{tabular}{|c|c|c|}
\hline Methods & Results & Ref. \\
\hline Two Spectrophoto-metric methods & $\begin{array}{l}\text { Sample: metronidazole. } \\
\text { Conc range: } 5-55 \mu \mathrm{g} / \mathrm{ml} \text { and } 5-60 \mu \mathrm{g} / \mathrm{ml} \text {. } \\
\text { Slope: } 0.0228 \text { and } 0.0174 \text {. } \\
\mathbf{r}^{2}: 0.9996 \text { and } 0.9997 . \\
\text { \% Re: } 99.15 \text { and } 99.54 \text {. } \\
\lambda_{\max }: 510 \mathrm{~nm} \text { and } 480 .\end{array}$ & {$[17]$} \\
\hline Spectrophoto-metric & $\begin{array}{l}\text { Sample: metronidazole. } \\
\text { Conc range: } 2.0-40.0 \mu \mathrm{g} / \mathrm{mL} \text {. } \\
\text { Slope: } 4.38 \times 10^{-2} . \\
\mathbf{r}^{2}: 0.9988 . \\
\text { LOD: } 0.76 \mu \mathrm{g} / \mathrm{mL}, \lambda_{\max }: 326 \mathrm{~nm} \text {. }\end{array}$ & [18] \\
\hline UV Spectrophoto-metric & $\begin{array}{l}\text { Sample: metronidazole. } \\
\text { Conc range: } 2-20 \mu \mathrm{g} / \mathrm{ml} \text {. } \\
\mathbf{r}^{2}: 0.998 . \\
\% \text { Re: } 98-102 \% \text {. } \\
\text { LOD: } 0.763 \mu \mathrm{g} / \mathrm{ml} \text {. } \\
\lambda_{\max }: 320 \mathrm{~nm} .\end{array}$ & [19] \\
\hline UV Spectrophoto-metric & $\begin{array}{l}\text { Sample: metronidazole. } \\
\text { Conc range: } 2-10 \mu \mathrm{g} / \mathrm{ml} . \\
\mathbf{r}^{2}: 0.9987 . \\
\text { \% Re: } 102.459, \lambda_{\max }: 277 \mathrm{~nm} .\end{array}$ & [20] \\
\hline UV Differential Spectrophoto-metric & $\begin{array}{l}\text { Sample: metronidazole. } \\
\text { Conc range: } 2-14 \mu \mathrm{g} / \mathrm{mL} \text {. } \\
\mathbf{r}^{2}: 0.999 . \\
\text { \% Re: } 99.93 . \\
\text { LOD: } 0.15 \mu \mathrm{g} / \mathrm{ml}, \lambda_{\max }: 324 \mathrm{~nm} .\end{array}$ & {$[21]$} \\
\hline
\end{tabular}




\begin{tabular}{|c|c|c|}
\hline Novel UV spectrophoto-meter & $\begin{array}{l}\text { Sample: metronidazole and furazolidone. } \\
\text { Conc range: between } 10 \text { to } 50 \mu \mathrm{g} / \mathrm{mL} \text {, and between } 5 \text { to } 25 \\
\mu \mathrm{g} / \mathrm{mL} \text {. } \\
\mathbf{r}^{2}: 0.9992,0.9996 . \\
\text { \% Re: } 98.16 \text { and } 98.44 \text {. } \\
\text { Slope: } 0.0277 \text { and } 0.0600 . \\
\text { LOD: } 0.323 \mu \mathrm{g} / \mathrm{ml}, 0.443 \mu \mathrm{g} / \mathrm{ml} \text {. } \\
\lambda_{\max }: 319 \text { and } 364 \mathrm{~nm} \text {. }\end{array}$ & {$[22]$} \\
\hline UV-visible Spectrophoto-metric & $\begin{array}{l}\text { Sample: metronidazole. } \\
\text { Conc range: } 1 \text { to } 15 \mu \mathrm{g} / \mathrm{ml} \text {. } \\
\mathbf{r}^{2} \text { : } 0.9994 . \\
\text { \% Re: } 98.80 . \\
\text { LOD: } 0.4277 \mu \mathrm{g} / \mathrm{ml} \text {. } \\
\lambda_{\max }: 320 \mathrm{~nm} .\end{array}$ & [23] \\
\hline Extractional spectrophoto-metric & $\begin{array}{l}\text { Sample: metronidazole. Tinidazole, ornidazole and secnidazole. } \\
\text { Conc range: } 2.50-22.50,2.50-30,7.50-35 \text { and } 5-30 \mu \mathrm{gml}^{-1} \text {. } \\
\text { Slope: } 3.15 \times 10^{-2}, 4.56 \times 10^{-2}, 5.14 \times 10^{-2} \text { and } 4.66 \times 10^{-2} \text {. } \\
\mathbf{r}^{2}: 0.9995,0.9995,0.9995 \text { and } 0.9996 \\
\text { LOD: } 5.33 \times 10^{-2}, 5.16 \times 10^{-2}, 5.01 \times 10^{-2} \text { and } 4.67 \times 10^{-2} \mu \mathrm{g} / \mathrm{ml} \text {. } \\
\lambda_{\max }: 419,418,420 \text { and } 416 \mathrm{~nm} \text {. }\end{array}$ & [24] \\
\hline
\end{tabular}

\section{Conclusions}

In tables 1,2 , and 3 , a variety of theoretical studies of three analytical methods for calculating metronidazole were included. It turns out from reviewing these studies that, the best way to calculate metronidazole is (HPLC) high performance liquid chromatography. This method gave a wide range of concentrations that were specified in $\mathrm{ng} / \mathrm{ml}$ and $\mu \mathrm{g} / \mathrm{ml}$, as well as low detection limit plus the most commonly used solvents are acetonitrile and methanol. As for spectrophotometric and ion selective electrodes, these methods are low cost considering quality control analysis compounds in pharmaceutical preparations. In addition, they are easy to use in terms of their application in calculating metronidazole in pharmaceutical samples.

\section{References}

[1] British pharmacopoeia; "Medicinal and Pharmaceutical Substances," published by The Stationery Office on behalf of the Medicines and Healthcare products Regulatory Agency (MHRA); Vol. 1 \& 2; pp. 1406$1407 ; 2014$.

[2] Lamp, Kenneth C., Freeman CD, Klutmam NE. "Pharmacokinetics and pharmacodynamics of the nitroimidazole antimicrobials." Clinical pharmacokinetics 36.5 (1999): 353-373.

[3] Shemer, Hilla, Yasemin Kaçar Kunukcu, and Karl G. Linden. "Degradation of the pharmaceutical metronidazole via UV, Fenton and photo-Fenton processes." Chemosphere 63.2 (2006): 269-276.

[4] Adegoke, O. A., O. E. Umoh, and J. O. Soyinka. "Spectrophotometric determination of metronidazole and tinidazole via charge transfer complexation using chloranilic acid." Journal of the Iranian Chemical Society 7.2 (2010): 359-370.

[5] Tursynbolat, Satar, Yrysgul Bakytkarim, Jianzhi Huang, Lishi Wang. "Ultrasensitive electrochemical determination of metronidazole based on polydopamine/carboxylic multi-walled carbon nanotubes nanocomposites modified GCE." Journal of pharmaceutical analysis 8.2 (2018): 124-130.

[6] Saghravanian, Maliheh, Mahmoud Ebrahimia, Zarrin Es'haghib, and S. Ali Beyramabadia. "Experimental sensing and density functional theory study of an ionic liquid mediated carbon nanotube modified carbon-paste electrode for electrochemical detection of metronidazole." South African Journal of Chemistry 70 (2017): 29-37.

[7] $\mathrm{Li}, \mathrm{Xiaobo}$, and Guangri Xu. "Simultaneous determination of ranitidine and metronidazole in pharmaceutical formulations at poly (chromotrope 2B) modified activated glassy carbon electrodes." Journal of food and drug analysis 22.3 (2014): $345-349$

[8] Gong, Fu-Chun, Xiao-Bing Zhang, Can-Cheng Guo, Guo-Li Shen and RuQin Yu. "Amperometric metronidazole sensor based on the super molecular recognition by metalloporphyrin incorporated in carbon paste electrode." Sensors 3.4 (2003): 91-100.

[9] Ezzeldin, Essam, and Toqa M. El-Nahhas. "New analytical method for the determination of metronidazole in human plasma: application to bioequivalence study." Tropical Journal of Pharmaceutical Research 11.5 (2012): 799-805.

[10] Hussain, Shafique, and Muhammad Tayyab Ansari. "Quantitation of metronidazole in pharmaceutical suspension using high performance liquid chromatographic method." Pakistan Journal of Zoology 43.5 (2011).

[11] Maslarska, Vania, Boyka Tsvetkova, Lily Peikova, Stanislav Bozhanov. "RP-HPLC Method for Simultaneous Determination of Metronidazole and Ofloxacin in Synthetic Mixture." CBU International Conference Proceedings. Vol. 4. 2016.

[12] Elkhoudary, Mahmoud M., Randa A. Abdel Salam, and Ghada M. Hadad. "Development and optimization of HPLC analysis of metronidazole, diloxanide, spiramycin and cliquinol in pharmaceutical dosage forms using experimental design." Journal of chromatographic science 54.10 (2016): 1701-1712.

[13] Verma, Pratibha, Varsha Namboodiry, Soni Mishra, Ashok Bhagwat, Suvarna Bhoir "A stability indicating HPLC method for the determination of metronidazole using ecofriendly solvent as mobile phase component." Int J Pharm Pharm Sci 5 (2013): 496-501.

[14] Sivannarayana, P., and K. Rambabu. "Simultaneous assay of mupirocin and metronidazole in formulations using reverse phase-high performance liquid chromatography." International Journal of Bioassays 5.12 (2016): 51515155.

[15] Tavakoli, Naser, et al. "Development and validation of a simple HPLC method for simultaneous in vitro determination of amoxicillin and metronidazole at single wavelength." Journal of pharmaceutical and biomedical analysis 43.1 (2007): 325-329.

[16] Nandini R. Pai, and Deeptaunshu Atul Pusalkar. "Development and validation of liquid chromatographic method for Metronidazole." Der Pharmacia Sinica 5.1 (2014): 23-28.

[17] Thulasamma, P., and P. Venkateswarlu. "Spectrophotometric method for the determination of metronidazole in pharmaceutical pure and dosage forms." Rasayan J. Chem 2.4 (2009): 865-868.

[18] Nagwa A H.S. Ahmida, MOona A. Esmael, Eman A. Winse, N. El-Enany, and F. Belal. "Difference Spectrophotometric Method for the Determination of Metronidazole in Tablets." Asian Journal of Chemistry 21.1 (2009):755762.

[19] Swetha Santhoshi Palla, Suresh T, D Sireesha, B Vasudha. "Development and Validation of UV Spectrophotometric Method for Estimation of Metronidazole in Tablet Dosage Form." International Journal of Pharma Research and Health Sciences 4.1 (2016): 968-971.

[20] Das, Joyani, and Manabendra Dhua. "UV-spectrophotometric assay method 
development and validation of metronidazole in bulk and tablet formulation." J of Pharm Sci Tech 3 (2014): 109.

[21] Mastanamma, S. K., K. Sravani, and T. Anil. "UV differential spectrophotometric method for the estimation of metronidazole in bulk and pharmaceutical formulation." Rasayan J. Chem 8.3 (2015): 303-309.

[22] Jain, Ruchi, et al. "Novel UV spectrophotometer methods for quantitative estimation of metronidazole and furazolidone using mixed hydrotropy solubilization." Arabian Journal of Chemistry 10.2 (2017): 151-156.
[23] Sampson Opoku, Isaac Ayensu, Abena Amponsaa Brobbey, Kofi Aryee Adjavon. "Metronidazole Analysis: Method Development and Validation via Hydrotropic Solubilization." Human 12.4 (2018): 1-13.

[24] Darwish, Khaled M., Ismail Salama, Samia Mostafa, and Mohamed ElSadek. "Extractional spectrophotometric analysis of metronidazole, tinidazole, ornidazole and secnidazole bases through acid-dye complexation using bromothymol blue dye." Pakistan journal of pharmaceutical sciences $25.1(2012)$

Cite this article as: Sarra A. Abrahem, Abdul kader S, Suhad A. Ibrahim, Different analytical methods for the determination of metronidazole -A review, International Journal of Research in Engineering and Innovation Vol-4, Issue-2 (2020), 86-90.

https://doi.org/10.36037/IJREI.2020.4202. 